\title{
Review of Corrosion Modes for Alloy 22 Regarding Lifetime Expectancy of Nuclear Waste Containers
}

\author{
R. B. Rebak, J. C. Estill
}

This article was submitted to 2002 Fall Meeting of the Materials Research Society in Boston, MA, December 2 - 6, 2002

\section{November 15, 2002}

Lawrence

Livermore

National

Laboratory

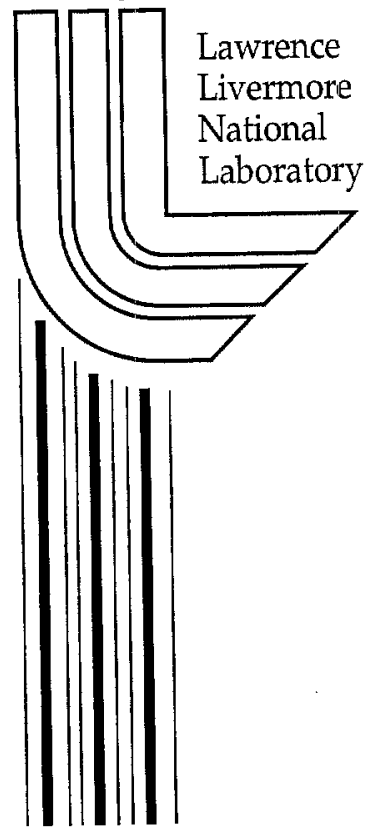




\section{DISCLAIMER}

This document was prepared as an account of work sponsored by an agency of the United States Government. Neither the United States Government nor the University of California nor any of their employees, makes any warranty, express or implied, or assumes any legal liability or responsibility for the accuracy, completeness, or usefulness of any information, apparatus, product, or process disclosed, or represents that its use would not infringe privately owned rights. Reference herein to any specific commercial product, process, or service by trade name, trademark, manufacturer, or otherwise, does not necessarily constitute or imply its endorsement, recommendation, or favoring by the United States Government or the University of California. The views and opinions of authors expressed herein do not necessarily state or reflect those of the United States Government or the University of California, and shall not be used for advertising or product endorsement purposes.

This is a preprint of a paper intended for publication in a journal or proceedings. Since changes may be made before publication, this preprint is made available with the understanding that it will not be cited or reproduced without the permission of the author.

This work was performed under the auspices of the United States Department of Energy by the University of California, Lawrence Livermore National Laboratory under contract No. W-7405-Eng-48.

This report has been reproduced directly from the best available copy.

Available electronically at http://www.doc.gov/bridge

Available for a processing fee to U.S. Department of Energy

And its contractors in paper from

U.S. Department of Energy

Office of Scientific and Technical Information

P.O. Box 62

Oak Ridge, TN 37831-0062

Telephone: (865) 576-8401

Facsimile: (865) 576-5728

E-mail: reports@adonis.osti.gov

Available for the sale to the public from

U.S. Department of Commerce

National Technical Information Service

5285 Port Royal Road

Springfield, VA 22161

Telephone: (800) 553-6847

Facsimile: (703) 605-6900

E-mail: orders@ntis.fedworld.gov

Online ordering: http://www.ntis.gov/ordering.htm

\section{OR}

Lawrence Livermore National Laboratory

Technical Information Department's Digital Library

http://www.llnl.gov/tid/Library.html 
Paper II4.1 to be presented at the 2002 Fall Meeting of the Materials Research Society in Boston (MA), 2-6 December 2002.

\title{
Review of Corrosion Modes For Alloy 22 Regarding Lifetime Expectancy of Nuclear Waste Containers
}

Raúl B. Rebak and John C. Estill

Lawrence Livermore National Laboratory

7000 East Ave. L-631

Livermore, CA 94550, USA

\begin{abstract}
Alloy 22 (UNS N06022) was selected to fabricate the corrosion resistant outer barrier of a two-layer waste package container for nuclear waste at the designated repository site in Yucca Mountain in Nevada (USA). A testing program is underway to characterize and quantify three main modes of corrosion that may occur at the site. Current results show that the containers would perform well under general corrosion, localized corrosion and environmentally assisted cracking (EAC). For example, the general corrosion rate is expected to be below $100 \mathrm{~nm} / \mathrm{year}$ and the container is predicted to be outside the range of potential for localized corrosion and environmentally assisted cracking.
\end{abstract}

\section{INTRODUCTION}

Yucca Mountain has recently been designated the site for geological disposal of commercial nuclear spent fuel and some other forms of high-level nuclear waste in the United States. Yucca Mountain is located about $160 \mathrm{~km}$ northwest of Las Vegas in the state of Nevada on land owned by the federal government [1]. The overall strategy in isolating highlevel nuclear waste is to make use of the natural barriers present in the host geologic site along with the construction of a series of engineered barriers. The current waste package design consists of two concentric metal containers. The outer container would be made of Alloy 22 or UNS N06022, which is among the most corrosion resistant of all engineering materials. The approximate composition of Alloy 22 (in weight \%) is: $\sim 56 \mathrm{Ni}, 22 \mathrm{Cr}, 13 \mathrm{Mo}$, $3 \mathrm{~W}$ and $3 \mathrm{Fe}$. The purpose of this outer container is to provide protection against corrosion. The inner container would be thicker and made of nuclear grade type $316 \mathrm{~L}$ stainless steel or UNS S31603. The intended purpose of the inner barrier is to provide shield for radiation and mechanical integrity. The engineering barrier also includes a detached drip shield that would be emplaced above the waste package to deflect any falling water from the rock onto the container. The proposed material for the drip shield is Titanium Grade 7 or UNS R52400 [1].

It is required that the containers would not release radioactive material to the surrounding mountain for several thousands of years. Due to radioactive decay, the temperature of the container may rise to a maximum of nearly $160^{\circ} \mathrm{C}$ during the first period of emplacement $(\sim 1,000$ years). The magnitude of the temperature depends on the number of containers per unit length of the emplacement tunnels.

The container may corrode only if water is present. The climate at Yucca Mountain is dry and water quantities reaching the waste package surface are limited. In the improbable case that water enters in contact with the container, it would be in the form of a multi-ionic 
solution. This solution may form through two different mechanisms, namely (1) Dripping from the drift wall and concentrating on the container and (2) Deliquescence of salt or mountain dust that may accumulate on top of the container during dry periods. In both cases the solution that may enter in contact with the container would be concentrated. The ground waters that are associated with Yucca Mountain have been well characterized [2,3]. Table 1 shows the composition of underground water $(\mathrm{J}-13)$ and pore water from the repository site. In both types of water, a high concentration of nitrate develops (Table 1) [3]. The environment may also be altered by microbial activity (e.g. bacteria and fungi) and by radiation, which may cause radiolysis of water. Table 1 also shows the composition of laboratory-prepared concentrated aqueous solutions that could be representative of environments that would enter in contact with the container.

Table 1: Composition of Representative Environments in $\mathrm{mg} / \mathrm{L}$

\begin{tabular}{lccccc}
\hline Ton & $\begin{array}{c}\text { J-13 } \\
\text { Well Water } \\
\text { pH 7.4 }\end{array}$ & $\begin{array}{c}\text { Unsaturated } \\
\text { Zone (UZ) } \\
\text { Pore Water } \\
\text { pH 5.6 }\end{array}$ & $\begin{array}{c}\text { Simulated } \\
\text { Concentrated } \\
\text { Water (SCW) } \\
\text { pH 10.3 }\end{array}$ & $\begin{array}{c}\text { Simulated } \\
\text { Acidified } \\
\text { Water (SAW) } \\
\text { pH 2.8 }\end{array}$ & $\begin{array}{c}\text { "1000-fold" } \\
\text { Pore Water } \\
\text { pH 6.3 }\end{array}$ \\
\hline $\mathrm{K}^{+}$ & 5.04 & 0.01 & 3400 & 3400 & 661 \\
$\mathrm{Na}^{+}$ & 45.8 & 9 & 40900 & 40900 & 727 \\
$\mathrm{Mg}^{2+}$ & 2.01 & 12 & $<1$ & 1000 & 470 \\
$\mathrm{Ca}^{2+}$ & 13 & 65 & $<1$ & 1000 & 273 \\
$\mathrm{~F}^{-}$ & 2.18 & 0 & 1400 & 0 & $<251$ \\
$\mathrm{Cl}^{-}$ & 7.14 & 77 & 6700 & 24250 & 681 \\
$\mathrm{NO}_{3}^{-}$ & 8.78 & 12 & 6400 & 23000 & 501 \\
$\mathrm{SO}_{4}{ }^{2-}$ & 18.4 & 79 & 16700 & 38600 & 25 \\
$\mathrm{HCO}_{3}^{-}$ & 128.9 & 66 & 70000 & 0 & $<2.2$ \\
$\mathrm{SiO}_{2}$ (aq) & 61.1 & 46 & $\sim 40$ & $\sim 40$ & 52 \\
& & & & & \\
\hline
\end{tabular}

\section{POTENTIAL CORROSION DEGRADATION MODES OF ALLOY 22}

Since the maximum temperature of the containers is approximately $160^{\circ} \mathrm{C}$, dry oxidation is not considered a life-limiting degradation mode. If water is present, there are three types of corrosion degradation modes that may occur. These an: (1) General or uniform corrosion, (2) Localized corrosion and (3) Environmentally assisted cracking (EAC). Figure 1 outlines how these three types of corrosion may impact the lifetime performance of the containers. Obviously, all types of corrosion will be influenced by the metallurgical condition of the alloy and the type of environment that is present. Metallurgical condition includes for example welded vs. wrought and annealed vs. aged microstructures. The environmental aspect includes temperature, solution composition (redox potentials) and effect of radiation or microbial activity. Furthermore, both the metallurgical and environmental conditions will determine the free corrosion potential $\left(\mathrm{E}_{\mathrm{cor}}\right)$ of the container. 


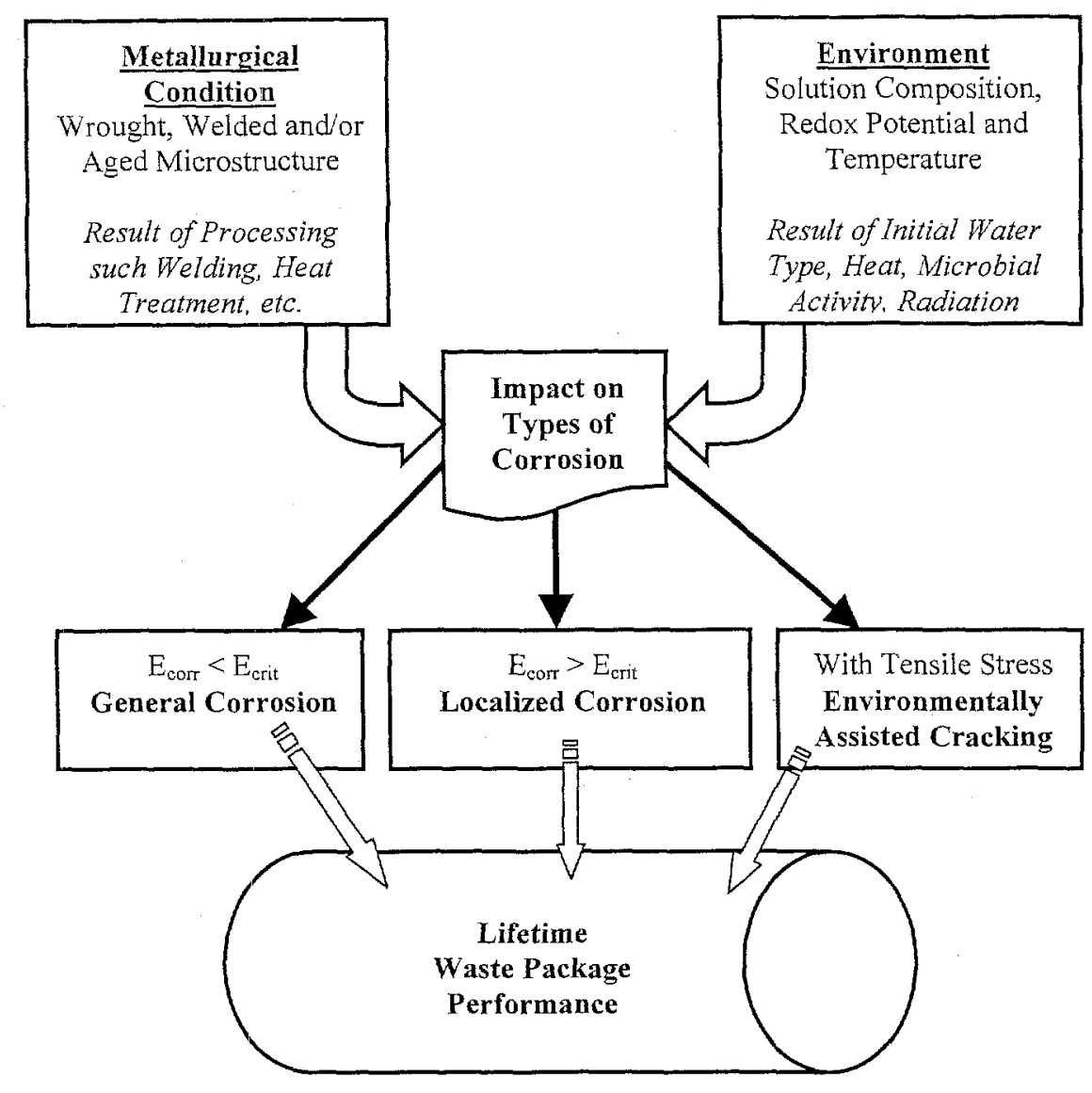

FIGURE 1: General Model For Corrosion Degradation of Alloy 22

\section{General or Uniform Corrosion}

General corrosion (or passive corrosion) is the uniform thinning of the container at its corrosion potential ( $E_{c o r r}$ ). The degradation model assumes that general corrosion at $E_{\text {corr }}$ will progress uniformly over a large surface at a (time-independent) constant rate. The model assumes that the depth of penetration ( $\mathrm{x}$ in $\mathrm{nm}$ ) or thinning of the container is equal to the corrosion rate ( $\mathrm{CR}$ in $\mathrm{nm}$ /year) multiplied by the time ( $\mathrm{t}$ in years) that the container is exposed to an environment under which general corrosion occurs. That is, $x=C R \cdot t$. General corrosion rates are being measured using long-term weight-loss immersion tests and shortterm electrochemical methods. Values of corrosion rate are being determined in realistic multi-ionic solutions in a wide range of temperatures, $\mathrm{pH}$ and $\mathrm{E}_{\mathrm{corr}}$. Table 2 shows values of corrosion rates determined under different testing conditions using different testing methods. Farmer et al. [4] reported that after 2-year immersion of Alloy 22 coupons in concentrated aqueous electrolytes from $\mathrm{pH} 2.8$ to 10 in the temperature range between $60^{\circ} \mathrm{C}$ and $90^{\circ} \mathrm{C}$, the average corrosion rate by mass loss was approximately $20 \mathrm{~nm} /$ year (Table 2). Rebak et al. [5] performed electrochemical impedance studies of MA and aged Alloy 22 at $\mathrm{E}_{\mathrm{corr}}$ in J-13 water at $95^{\circ} \mathrm{C}$. After immersion times of less than three hours in normally aerated solutions, they reported corrosion rates of approximately $200 \mathrm{~nm} / \mathrm{year}$ (Table 2). Dunn and Brossia [6] performed constant potential tests on Alloy 22 immersed in deaerated $0.028 \mathrm{M}$ and $0.5 \mathrm{M}$ $\mathrm{NaCl}$ solutions of $\mathrm{pH} 2.7$ and 8 at $20^{\circ} \mathrm{C}$ and $95^{\circ} \mathrm{C}$. After holding the potential constant for 48 $\mathrm{h}$ in the range between 0 and $+0.4 \mathrm{~V}$ [SCE], they reported passive currents that translated into 
corrosion rates of less than $500 \mathrm{~nm} /$ year. Lloyd et al. [7] performed constant potential tests on Alloy 22 in deaerated $1 \mathrm{M} \mathrm{NaCl}+0.1 \mathrm{M} \mathrm{H}_{2} \mathrm{SO}_{4}$ solution at temperatures between $25^{\circ} \mathrm{C}$ and $85^{\circ} \mathrm{C}$. At $75^{\circ} \mathrm{C}$ and at an applied potential of $+200 \mathrm{mV}[\mathrm{Ag} / 0.1 \mathrm{MAgCl}]$, they reported a current density of $1.58 \times 10^{-8} \mathrm{~A} / \mathrm{cm}^{2}$ after $10 \mathrm{~h}$ of testing. This current density translates into a corrosion rate of $138 \mathrm{~nm} /$ year (Table 2). Evans and Rebak [8] carried out polarization resistance tests at the $E_{\text {cor }}$ of Alloy 22 in simulated acidified water (SAW) (Table 1). After an immersion of $1 \mathrm{~h}$ in deaerated conditions they reported corrosion rates ranging from 480 $\mathrm{nm} /$ year at $30^{\circ} \mathrm{C}$ to $1440 \mathrm{~nm} /$ year at $90^{\circ} \mathrm{C}$ [8]. However, after one-week immersion in aerated $\mathrm{SAW}$, the corrosion rate decreased more than one order of magnitude to $23 \mathrm{~nm} /$ year at $30^{\circ} \mathrm{C}$ and to $103 \mathrm{~nm} /$ year at $90^{\circ} \mathrm{C}$ (Table 2) [8]. Lian et al. [9] performed constant potential tests in aerated and deaerated SAW and SCW (Table 1) at $90^{\circ} \mathrm{C}$ and at potential values of $+0.1 \mathrm{~V}$ and $+0.4 \mathrm{~V}[\mathrm{Ag} / \mathrm{AgCl}]$. For example, after one day testing in deaerated solutions at $+0.1 \mathrm{~V}$, they reported corrosion rates of $460 \mathrm{~nm} /$ year in SAW and $1250 \mathrm{~nm} / \mathrm{year}$ in SCW [9]. After they extrapolated the one-day decaying current density values to one year, the corrosion rates became $21 \mathrm{~nm} /$ year and $100 \mathrm{~nm} / \mathrm{year}$, respectively [9]. Recently, after analyzing the results of 122 specimens exposed for more than 5 years in multionic solutions, Wong et al. reported that the total average corrosion rate of Alloy 22 was less than $10 \mathrm{~nm} /$ year [10]. This average corrosion rate included data for two temperatures $\left(60\right.$ and $\left.90^{\circ} \mathrm{C}\right)$, two metallurgical conditions (wrought and welded), three electrolyte solutions ( $\mathrm{pH} 2.8$ to 10) and vapor plus liquid phases [10]. The available data in the literature reported above [4-10] shows that the general corrosion rate of Alloy $22 \mathrm{in} \mathrm{acidic} \mathrm{to} \mathrm{alkaline} \mathrm{solutions} \mathrm{is} \mathrm{expected} \mathrm{to} \mathrm{be} \mathrm{below} 100 \mathrm{~nm} / \mathrm{year}$, or a penetration of $1 \mathrm{~mm}$ over a period of 10,000 years.

Table 2: General Corrosion Rates for MA Wrought Alloy 22

\begin{tabular}{|l|c|c|c|}
\hline Reference & Environment & $\begin{array}{c}\text { Measurement Method, } \\
\text { Conditions }\end{array}$ & $\begin{array}{c}\text { Corr. Rate } \\
\text { (nm/year) }\end{array}$ \\
\hline Farmer et al. [4] & $\begin{array}{c}\text { Concentrated aerated } \\
\text { multi-ionic electrolytes } \mathrm{pH} \\
2.8 \text { to } 10 \text { at } 60^{\circ} \mathrm{C} \text { and } 90^{\circ} \mathrm{C}\end{array}$ & $\begin{array}{c}\text { Weight-loss Immersion } \\
\text { Tests for } 2 \text { years at } \mathrm{E}_{\mathrm{cor}}\end{array}$ & 20 \\
\hline Rebak et al. [5] & Aerated $\mathrm{J}-13, \mathrm{pH} 7.4,95^{\circ} \mathrm{C}$ & $\begin{array}{c}\mathrm{AC} \text { Impedance at } \mathrm{E}_{\text {corr }} \\
\text { after } \sim 3 \text { h immersion }\end{array}$ & 200 \\
\hline Lloyd et al. [7] & $\begin{array}{c}\text { Deaerated } 1 \mathrm{M} \mathrm{NaCl}+0.1 \\
\mathrm{M} \mathrm{H}_{2} \mathrm{SO}_{4} \text { solution at } 75^{\circ} \mathrm{C}\end{array}$ & $\begin{array}{c}\text { Constant Potential }+200 \\
\mathrm{mV}[\mathrm{Ag} / \mathrm{AgCl}] \text { for } 10 \mathrm{~h}\end{array}$ & 138 \\
\hline $\begin{array}{l}\text { Evans and } \\
\text { Rebak [8] }\end{array}$ & $\begin{array}{c}\text { One week in aerated } \mathrm{SAW} \\
\mathrm{pH} 2.8 \text { at } 30^{\circ} \mathrm{C} \text { to } 90^{\circ} \mathrm{C}\end{array}$ & $\begin{array}{c}\text { Polarization Resistance } \\
\text { at } \mathrm{E}_{\text {corr }}\end{array}$ & 23 to 103 \\
\hline Wong et al. [10] & $\begin{array}{c}\text { Concentrated aerated } \\
\text { multi-ionic electrolytes } \mathrm{pH} \\
2.8 \text { to } 10 \text { at } 60^{\circ} \mathrm{C} \text { and } 90^{\circ} \mathrm{C}\end{array}$ & $\begin{array}{c}\text { Vapor and Liquid Mass- } \\
\text { Loss Immersion Tests } \\
\text { for }>5 \text { years at } \mathrm{E}_{\text {corr }}\end{array}$ & $<10$ \\
\hline
\end{tabular}

\section{Localized Corrosion}

Localized corrosion (crevice corrosion) is a type of corrosion in which the attack progresses at discrete sites or in a non-uniform manner. The degradation model (Figure 1) assumes that localized corrosion will only occur when $E_{\text {corr }}$ is equal or greater than a critical potential $\left(E_{\text {crit }}\right)$ for localized corrosion. That is, if $E_{\text {corr }}<E_{\text {crit }}$ general corrosion will occur. $E_{\text {crit }}$ can be defined as a certain potential above which the current density or corrosion rate of Alloy 22 increases significantly and irreversibly above the general corrosion rate of the passive metal. In environments that promote localized corrosion, $E_{\text {crit }}$ is the lowest potential 
that would trigger localized (e.g. crevice) corrosion. In environments that are benign towards localized corrosion $\mathrm{E}_{\text {crit }}$ would correspond to a transpassive or oxygen evolution potential. In every case, the margin of safety against localized corrosion will always be given by the value of $\Delta \mathrm{E}=\mathrm{E}_{\text {crit }}-\mathrm{E}_{\text {corr }}$. The higher the value of $\Delta \mathrm{E}$, the larger the margin of safety for localized corrosion. It is important to note here that the values of both $E_{\text {corr }}$ and $E_{\text {crit }}$ depend of the surface condition of Alloy 22, on the composition of the environment (e.g. chloride concentration) and the temperature. Additionally, the value of $E_{\text {crit }}$ depends on the way (method) it is measured. Researchers commonly use cyclic potentiodynamic polarization [11] or the Tsujikawa-Hisamatsu method [12] to determine localized corrosion (mostly crevice) repassivation potentials. This crevice repassivation potential is generally equated to $E_{\text {crit }}$

Alloy 22 is extremely resistant to localized corrosion such as pitting corrosion and crevice corrosion. Critical temperatures for pitting and crevice corrosion determined through immersion tests in aggressive solutions are always among the highest for nickel alloys [13, 14]. Electrochemical tests also showed that Alloy 22 was resistant to crevice corrosion.For example, Dunn et al. [15-17] showed that the repassivation potential for crevice corrosion ( $E_{\text {crit }}$ ) of Alloy 22 was approximately $300 \mathrm{mV}$ [SCE] in $1 \mathrm{M} \mathrm{NaCl}$ at $95^{\circ} \mathrm{C}$. Rebak et al. [14] performed cyclic polarization tests using seven types $\mathrm{Ni}-\mathrm{Cr}-\mathrm{Mo}$ alloys. They showed that the repassivation potential for MA Alloy 22 in $1 \mathrm{M} \mathrm{NaCl}$ solution at $50^{\circ} \mathrm{C}$ was above $400 \mathrm{mV}$ [SCE]. Evans and Rebak performed cyclic polarization experiments in $5 \mathrm{M} \mathrm{CaCl}_{2} \mathrm{pH} 6.4$ solutions [8]. They reported that the passivity breakdown potential was higher than $800 \mathrm{mV}$ [SSC] at $75^{\circ} \mathrm{C}$ and decreased to $195 \mathrm{mV}$ [SSC] at $90^{\circ} \mathrm{C}$ [8]. Electrochemical tests reported above [8, 14-17] showed that Alloy 22 was susceptible to localized (crevice) corrosion at high anodic potentials in pure concentrated chloride solutions such as sodium chloride [1417] and calcium chloride [8]. However, when nitrate was added to the chloride containing solution, the susceptibility of Alloy 22 to crevice corrosion decreased or disappeared [6,8, 18]. Dunn and Brossia reported that the crevice repassivation potential of welded Alloy 22 in $0.5 \mathrm{M} \mathrm{NaCl}$ at $95^{\circ} \mathrm{C}$ was $0 \mathrm{~V}$ [SCE] [6]. When $0.05 \mathrm{M}$ nitrate was added $\left(\mathrm{Cl}^{-} / \mathrm{NO}_{3}{ }^{-}=10\right)$ the crevice repassivation potential remained unchanged; however, when $0.1 \mathrm{M}$ and higher nitrate concentration was added $\left(\mathrm{Cl}^{-} / \mathrm{NO}_{3}{ }^{-} \leq 5\right)$, the crevice repassivation potential was near $350 \mathrm{mV}$ [SCE] and the alloy was free from crevice corrosion [6]. Kehler et al. [18] tested the susceptibility of Alloy 22 to crevice corrosion as a function of temperature and pH in $5 \mathrm{M}$ $\mathrm{LiCl}$ containing different amounts of oxyanions (sulfate and nitrate). They reported that as the ratio $\mathrm{Cl} /\left(\mathrm{NO}_{3}{ }^{-}+\mathrm{SO}_{4}{ }^{2-}\right)$ decreased from 100 to 10 to 1 , the susceptibility to crevice corrosion decreased [18]. Evans and Rebak [8] reported that the breakdown potential of Alloy 22 in 5 $\mathrm{M} \mathrm{CaCl}_{2}$ solution at $90^{\circ} \mathrm{C}$ was $0.195 \mathrm{~V}$ [SSC]; however, when $0.5 \mathrm{M} \mathrm{Ca}\left(\mathrm{NO}_{3}\right)$ was added $\left(\mathrm{Cl}^{-} / \mathrm{NO}_{3}{ }^{-}=10\right)$, the breakdown potential increased to $0.76 \mathrm{~V}$ [SSC] and the alloy was free from localized corrosion.

It is possible to initiate localized attack in Alloy 22, but the environmental circumstances for doing this are extreme. Of particular concern is an environment issuing from evaporative concentration of the pore water composition (Table 1), since this water would be "rich" in calcium chloride. Nevertheless, it is very unlikely that a pure calcium, sodium or lithium chloride environment would ever form under the repository conditions of Yucca Mountain. By the proper nature of the mountain dust, it is expected that inhibiting oxyanions such nitrate will always be present. Nonetheless, following the modeling criteria requiring a positive $\Delta \mathrm{E}$ value as a condition that shows resistance to localized corrosion, Alloy 22 would still be the right choice. Table 3 lists values of $E_{\text {corr }}$ and threshold potentials $\left(E_{20}\right)$ that could be related to $E_{\text {crit }}$ from the cited references above, showing that in all tested circumstances (even in pure high concentration chloride solutions) the value of $\Delta \mathrm{E}$ was positive. The values of $E_{20}$ in Table 3 corresponded to the potential value at which the current density was $20 \mu \mathrm{A} / \mathrm{cm}^{2}$. The values in Table 3 are a general guide for $\Delta \mathrm{E}$. A better choice 
would be to determine $\Delta \mathrm{E}$ using the crevice repassivation potential, which is currently being measured in a variety of environments.

Table 3: Parameters for Localized Corrosion Susceptibility

\begin{tabular}{|c|c|c|c|c|}
\hline Reference & Tested Conditions. Type of $\mathrm{E}_{\text {crit }}$ & $\begin{array}{l}E_{\text {corr }} \\
(\mathrm{mV})\end{array}$ & $\begin{array}{c}\mathrm{E}_{20} \\
(\mathrm{mV})\end{array}$ & $\begin{array}{c}\Delta \mathrm{E} \\
(\mathrm{mV})\end{array}$ \\
\hline Rebak et al. [5] & $\begin{array}{l}\text { Potentiodynamic Polarization in aerated J- } \\
\qquad 13,95^{\circ} \mathrm{C} \text {. Anodic Peak. }\end{array}$ & $\begin{array}{c}-300 \\
{[\mathrm{SCE}]}\end{array}$ & $\begin{array}{c}250 \\
{[\mathrm{SCE}]}\end{array}$ & 550 \\
\hline $\begin{array}{l}\text { Evans and } \\
\text { Rebak [8], Lian } \\
\text { et al. [9] }\end{array}$ & $\begin{array}{l}\text { Potentiodynamic Polarization in aerated } \\
\mathrm{SAW}, \mathrm{pH} 2.8,90^{\circ} \mathrm{C} \text {. Transpassivity }\end{array}$ & $\begin{array}{c}350 \\
{[\mathrm{SSC}]}\end{array}$ & $\begin{array}{c}700 \\
{[\mathrm{SSC}]}\end{array}$ & 350 \\
\hline Lian et al. [9] & $\begin{array}{l}\text { Potentiodynamic Polarization in aerated } \\
\mathrm{SCW}, \mathrm{pH} 7.8,90^{\circ} \mathrm{C} \text {. Anodic Peak }\end{array}$ & $\begin{array}{c}-300 \\
{[\mathrm{SSC}]}\end{array}$ & $\begin{array}{c}200 \\
{[\mathrm{SSC}]}\end{array}$ & 500 \\
\hline $\begin{array}{l}\text { Evans and } \\
\text { Rebak [8] }\end{array}$ & $\begin{array}{c}\text { Potentiodynamic Polarization in deaerated } \\
5 \mathrm{M} \mathrm{CaCl}_{2}, \mathrm{pH} 6.4 \text { at } 90^{\circ} \mathrm{C} \text {. Localized } \\
\text { Corrosion }\end{array}$ & $\begin{array}{l}-410 \\
{[\mathrm{SSC}]}\end{array}$ & [SSC] & 605 \\
\hline $\begin{array}{l}\text { Evans and } \\
\text { Rebak [8] }\end{array}$ & $\begin{array}{l}\text { Potentiodynamic Polarization in deaerated } \\
5 \mathrm{M} \mathrm{CaCl}_{2}+0.5 \mathrm{M} \mathrm{Ca}\left(\mathrm{NO}_{3}\right)_{2} \mathrm{pH} 5.8 \text { at } \\
90^{\circ} \mathrm{C} \text {. Transpassivity }\end{array}$ & $\begin{array}{l}-420 \\
{[\mathrm{SSC}]}\end{array}$ & $\begin{array}{c}760 \\
{[\mathrm{SSC}]}\end{array}$ & 1180 \\
\hline
\end{tabular}

\section{Environmentally Assisted Cracking (EAC)}

EAC is a phenomenon by which certain ductile metallic materials loose ductility in presence of tensile stresses in specific corrosive environment. That is, for EAC to ocar, the simultaneous presence of three factors must be present. These are (1) a susceptible microstructure, (2) tensile stresses and (3) an aggressive environment. If one or more of these variables is eliminated, EAC will not occur. Wrought mill annealed (MA) Alloy 22 is highly resistant to $\mathrm{EAC}$ in most environments, including acidic concentrated chloride solutions [17, 19-22]. Dunn et al. did not find EAC when they tested Alloy 22 in 14 molal $\mathrm{CI}$ (as $\mathrm{MgCl}_{2}$ ) at $110^{\circ} \mathrm{C}$ and 9.1 molal $\mathrm{LiCl}$ at $95^{\circ} \mathrm{C}$ under controlled potential $[17,19-20]$. They used wedge opening loaded double cantilever beam (DCB) and compact tension (CT) specimens at stress intensities in the range 32 to $47 \mathrm{MPa} \cdot \mathrm{m}^{1 / 2}$ for times as long a 52 weeks $[17,19-20]$. Rebak reported that Alloy 22 U-bend specimens did not suffer EAC when exposed to $45 \% \mathrm{MgCl}_{2}$ at $154^{\circ} \mathrm{C}$ for up to 6 weeks [21]. Estill et al. performed slow strain rate tests (SSRT) at a $1.6 \mathrm{x}$ $10^{-6} \mathrm{~s}^{-1}$ strain rate at the corrosion potential $\left(\mathrm{E}_{\mathrm{cor}}\right)$ in $4 \mathrm{M} \mathrm{NaCl}$ at $98^{\circ} \mathrm{C}$, saturated $\mathrm{CaCl}_{2}(>10$ $\left.\mathrm{M} \mathrm{Cl}^{-}\right)$at $120^{\circ} \mathrm{C}$ and $1 \% \mathrm{PbCl}_{2}$ at $95^{\circ} \mathrm{C}$ [22]. None of these specimens showed a loss of ductility or secondary cracking [22]. In a recent study, it has been reported that welded and wrought U-bend specimens exposed for more than 5 years to multi-ionic solutions (Table 1 ) of $\mathrm{pH} 2.8$ to 10 at $60^{\circ} \mathrm{C}$ and $90^{\circ} \mathrm{C}$ were free from EAC. [23]

Even though Alloy 22 is resistant to EAC in concentrated chloride solutions, it may be susceptible under other severe environmental conditions [24-27]. Andresen et al. tested the susceptibility of Alloy 22 to $\mathrm{EAC}$ at the corrosion potential $\left(\mathrm{E}_{\text {corr }}\right)$ in basic saturated water (BSW) at $110^{\circ} \mathrm{C}[24]$. This BSW multi-ionic solution is another version of concentrated solutions that might be obtained after evaporative tests of Yucca Mountain ground waters (more concentrated than SCW in Table 1). Using the reversing DC potential drop technique, Andresen et al. reported a crack grow rate of $5 \times 10^{-13} \mathrm{~m} / \mathrm{s}$ in a $20 \%$ cold-worked specimen loaded to a stress intensity of $30 \mathrm{MPa} \cdot \mathrm{m}^{1 / 2}$. This EAC testing was carried out in air saturated 
BSW water of $\mathrm{pH} \sim 13$. The testing conditions used by Andresen et al. were highly aggressive and, in spite of that, the measured crack growth rate was near the detection limit of the system [24]. Rebak et al. reported that Alloy 22 U-bend specimens suffered transgranular EAC when they were exposed for $336 \mathrm{~h}$ to aqueous solutions of $20 \% \mathrm{HF}$ at $93^{\circ} \mathrm{C}$ and to its corresponding vapor phase [25]. The liquid phase was more aggressive than the vapor phase [24]. Pulvirenti et al. reported transgranular cracking in one out of four Alloy $22 \mathrm{U}$-bend specimen exposed for 15 days at $250^{\circ} \mathrm{C}$ in concentrated ground water contaminated with 0.5 $\%$ lead $(\mathrm{Pb})$ and acidified to $\mathrm{pH} 0.5$ [26-27]. Estill et al. performed slow strain rate tests, cyclic loading tests and U-bend tests in large variety of environments (temperature, applied potential and solution composition) [22]. They only reported EAC on MA Alloy 22 through SSRT in saturated concentrated water (SCW) at $73^{\circ} \mathrm{C}$ and at a potential of $+0.4 \mathrm{~V}$ [SSC] [22]. Even though, Alloy 22 may be susceptible to environmentally assisted cracking in a few environments at $E_{c o r r}$ [25-27], these are not realistic for the Yucca Mountain emplacement site. There are not published results in which Alloy 22 would suffer EAC in multionic solutions at $E_{\text {corr }}$ King et al. [28] reported cracking in SCW solution only at applied anodic potentials at least $0.3 \mathrm{~V}$ higher than $E_{\text {corr }}$.

EAC is unlikely to initiate and grow in Alloy 22 in the repository conditions where the only stresses are residual fabrication (forming and welding) stresses. Nevertheless, it is planned to mitigate further the possibility of EAC by putting compressive stresses on the container surface. Assembly welds made during the container fabrication are expected to be solution annealed to remove residual stress and restore the alloy homogeneity in the welded region. This will help to mitigate any possible EAC initiation. Stress mitigation processes around the final closure weld (top lid onto the container body, filled with the waste form) have also been proposed. The two processes under active consideration are laser peening and burnishing. Laser peening produces a compressive stress layer on the welded waste package surface, and with optimization of the process, this layer achieves $\sim 3 \mathrm{~mm}$ in depth. Burnishing is a mechanical process by which the compressive stresses on the surface are applied via a rolling ball.

\section{CONCLUSIONS}

(1) The three corrosion failure modes that have been identified for the performance of the containers are general corrosion, localized corrosion and environmentally assisted cracking.

(2) It is expected that in relevant environments such as acidic and alkaline multi-ionic brines, Alloy 22 will remain passive. Under these conditions, general corrosion rates are expected to be below $100 \mathrm{~nm} /$ year.

(3) In multi-ionic brines, Alloy 22 is immune to localized corrosion. Crevice corrosion may occur in conditions of pure concentrated chloride solutions near the boiling point at anodic potentials that are at least $300 \mathrm{mV}$ more positive than $\mathrm{E}_{\text {corr }}$.

(4) Alloy 22 is resistant to environmentally assisted cracking (EAC) in relevant conditions of Yucca Mountain. The elimination of residual stresses should further mitigate the occurrence of EAC.

\section{ACKNOWLEDGMENTS}

This work was performed under the auspices of the U. S. Department of Energy by the University of California Lawrence Livermore National Laboratory under contract No. W7405-Eng-48. This work is supported by Yucca Mountain Site Characterization Project. 


\section{REFERENCES}

1. Yucca Mountain Science and Engineering Report, U. S. Department of Energy, Office of Civilian Radioactive Waste Management, DOE/RW-0539, Las Vegas, NV, May 2001.

2. J. E. Harrar, J. F. Carley, W. F. Isherwood, and E. Raber, Report on the Committee to Review the Use of J13 Well Water in Nevada Nuclear Waste Storage Investigations, LLNL UCID Report 21867 (University of California, Livermore, January 1990).

3. N. D. Rosenberg, G. E. Gdowski and K. G. Knauss, Applied Geochemistry, 16, 1231 (2001).

4. J. C. Farmer, R. D. McCright, G. E. Gdowski, F. Wang, T. S. E. Summers, P. Bedrossian, J. M. Horn, T. Lian, J. C. Estill, A. Lingenfelter and W. Haalsey, PVP-ASME, 408, 53 (New York, NY: ASME, 2000).

5. R. B. Rebak, T. S. E. Summers, T. Lian, R. M. Carranza, J. R. Dillman, T. Corbin and P. Crook, Paper 542, Corrosion/02, NACE International, (Houston, TX : 2002).

6. D. S. Dunn and C. S. Brossia, Paper 548, Corrosion/02, NACE International, (Houston, TX: 2002).

7. A. C. Lloyd, D. W. Shoesmith, N. S. MeIntyre and J. J. Noël, submitted to Journal of The Electrochemical Society (September 2001).

8. K. J. Evans and R. B. Rebak, presented at the Robert P. Frankenthal Symposium at the Spring 2002 Electrochemical Society Conference in Philadelphia May 13-17 (to be published by ECS, 2002).

9. T. Lian, J. C. Estill, G. A. Hust, D. V. Fix and R. B. Rebak, Pressure Vessels and Piping ASME Conference in Vancouver (Canada) 4-8 August 2002, PVP-Vol. 449, 67 (ASME, 2002: New York, NY).

10. L. L. Wong, D. V. Fix, J. C. Estill, R. D. McCright and R. B. Rebak paper II4.4 presented at the Fall 2002 meeting of the Materials Research Society, Boston 2-6 December 2002 (to be published).

11. Annual Book of the ASTM Standards, Volume 03,02, Standard G 61 (ASTM, 2001 : West Conshohocken, PA).

12. S. Tsujikawa and Y. Hisamatsu, Corr. Eng. (Japan), 29, 37 (1980).

13. R. B. Rebak in Corrosion and Environmental Degradation, Volume II, Wiley-VCH, 69-111 (Weinheim, Germany 2000).

14. R.B. Rebak and P. Crook, "Critical Factors in Localized Corrosion III," 98-17, 289 (Pennington, NJ: The Electrochemical Society, 1999).

15. K. A. Gruss, G. A. Cragnolino, D. S. Dunn, N. Sridhar, Paper 149, Corrosion/98, NACE International; (Houston, TX 1998).

16. D. S. Dunn, G. A. Cragnolino and N. Sridhar in Scientific Basis for Nuclear Waste Management XXIII, Materials Research Society, 608, 89 (MRS, 2000:Warrendale, PA).

17. D. S. Dunn and C. S. Brosia, Paper 125, Corrosion/01 (NACE International, 2001: Houston, TX).

18. B. A. Kehler, G. O. Tlevbare and J. R. Scully, Corrosion, 57, 1042 (2001).

19. Y.-M. Pan, D. S. Dunn and G. A. Cragnolino in Environmentally Assisted Cracking: Predictive Methods for Risk Assessment and Evaluation of Materials, Equipment and Structures, ASTM STP 1401 (ASTM, 2000: West Conshohocken, PA), pp. 273-288.

20. D. S. Dunn, Y.-M. Pan and G. A. Cragnolino, Paper 425, Corrosion/02 (NACE International, 2002: Houston, TX).

21. R. B. Rebak in Environmentally Assisted Cracking: Predictive Methods for Risk Assessment and Evaluation of Materials, Equipment and Structures, ASTM STP 1401 (ASTM, 2000: West Conshohocken, PA), pp. 289-300.

22. J. C. Estill, K. J. King, D. V. Fix, D. G. Spurlock, G. A. Hust, S. R. Gordon, R. D. McCright, G. M. Gordon and R. B. Rebak, Paper 535, Corrosion/02 (NACE International, 2002: Houston, TX).

23. D. V. Fix, J. C. Estill, K. J. King, S. D. Day and R. B. Rebak, Paper 03542, Corrosion/03 (NACE International, 2003: Houston, TX).

24. P. L. Andresen, P. W. Emigh, L. M. Young and G. M. Gordon, Paper 130, Corrosion/01, (NACE International, 2001: Houston, TX).

25. R. B. Rebak, J. R. Dillman, P. Crook and C. V. V. Shawber, Materials and Corrosion, 52 (2001), pp. 289297.

26. A. L. Pulvirenti, K. M. Needham, M. A. Adel-Hadadi, C. R. Marks, J. A. Gorman and A. Barkatt, 713, 89 (MRS, 2002: Warrendale, PA)

27. A. L. Pulvirenti, K. M. Needham, M. A. Adel-Hadadi, A. Barkatt, C. R. Marks and J. A. Gorman, Paper 551, Corrosion/02 (NACE International, 2002: Houston, TX).

28. K. J. King, J. C. Estill and R. B. Rebak, Pressure Vessels and Piping ASME Conference in Vancouver (Canada) 4-8 August 2002, PVP-Vol. 449, 103 (ASME, 2002: New York, NY). 